\title{
Rubelose em plantas de bacurizinho no Pará: primeiro relato
}

\author{
Rosemary Corrêa da Costa ${ }^{1}$; Jaqueline Rosemeire Verzignassi ${ }^{2}$; Luiz Sebastião Poltronieri ${ }^{3}$; Ruth Linda Benchimol ${ }^{3}$; \\ Eudes de Arruda Carvalho ${ }^{3}$
}

${ }^{1}$ Universidade Federal Rural da Amazônia, Av. Tancredo Neves, 2501, CEP 66077-530, Belém, PA. ${ }^{2}$ Embrapa Gado de Corte, Avenida Rádio Maia, 830, CEP 79106-550, Campo Grande, MS. ${ }^{3}$ Embrapa Amazônia Oriental, Tv. Enéas Pinheiro, S/N, CEP 66095-100, Belém, PA

Autor para correspondência: Jaqueline Rosemeire Verzignassi (jaqueline@cnpgc.embrapa.br)

Data de chegada: 02/07/2012. Aceito para publicação em: 20/08/2012.

A espécie Rheedia acuminata (Ruiz et Pav.) Planch. et Triana Clusiaceae, conhecida como bacurizinho (no Pará), bacuri-de-espinhos (no Amazonas), limãozinho (em Mato Grosso), pakoeli e swampoepakoeli (no Suriname), é uma espécie frutífera de pequeno porte, nativa da Amazônia e raramente cultivada, pois seus frutos, embora comestíveis, apresentam escasso rendimento da parte comestível. Entretanto, esta espécie é utilizada como porta-enxerto ananicante para outras espécies frutíferas dos gêneros Rheedia e Garcinia, que apresentam porte elevado, como o bacuriparizeiro (Rheedia macrophylla Planch. (Mart.) et Triana) e o mangostãozeiro (Garcinia mangostana L.). Em Belém, PA, lesões necróticas de coloração rósea foram detectadas causando depressão e rachadura na casca dos ramos de bacurizinho (Figura 1). Partes de plantas severamente infectadas, apresentando secamento e morte de ramos, foram enviadas ao Laboratório de Fitopatologia da Embrapa Amazônia Oriental, em Belém, PA, onde, do material infectado, foram retiradas porções de micélio, que foram dispostas em placas de Petri contendo o meio de cultura ágar-água. Após o crescimento das hifas, realizou-se a repicagem para o meio de cultura BDA, com a finalidade de multiplicação e identificação do patógeno. Por meio de observações macroscópicas e microscópicas, foi possível identificar o fungo Erythricium salmonicolor (Berk et Broome) Burds. sin. Phanerochaete salmonicolor (Berk. Et Broome)
Jülich, agente causal da rubelose ou mal rosado. Os sintomas da doença iniciam-se nas forquilhas dos ramos principais, onde o teor de umidade é maior, favorecendo o desenvolvimento do micélio do fungo. Como sinais típicos da doença, inicialmente, os ramos são recobertos por micélio de coloração branca, algumas vezes visto a olho nu, em formato de leque, brilhante, sobre o tecido apodrecido da casca. Posteriormente, o micélio adquire coloração rósea que depois desaparece, deixando filamentos longos, esbranquiçados ou acinzentados, que penetram no ramo. O fungo penetra, primeiramente, em tecidos da casca dos ramos e depois em camadas mais internas do lenho. As lesões produzem uma espécie de goma no início da infecção. Sobre a casca dos ramos formase uma crosta rósea, que com o tempo, racha e perde a cor viva. A casca ainda apresenta fendas decorrente da morte dos tecidos. Com o comprometimento de camadas mais internas de lenho, os ramos secam da extremidade até a área onde as lesões estão localizadas. Os frutos de ramos afetados não completam a maturação e caem prematuramente. Partes das plantas coletadas com sintomas e utilizadas para as análises foram herborizadas e armazenadas no Herbário da Embrapa Amazônia Oriental sob o número de registro 187.900. A rubelose já foi constatada no Estado do Pará afetando pimenteira-do-reino, seringueira e citrus. Este é o primeiro registro da rubelose ou mal rosado em bacurizinho no Estado do Pará.
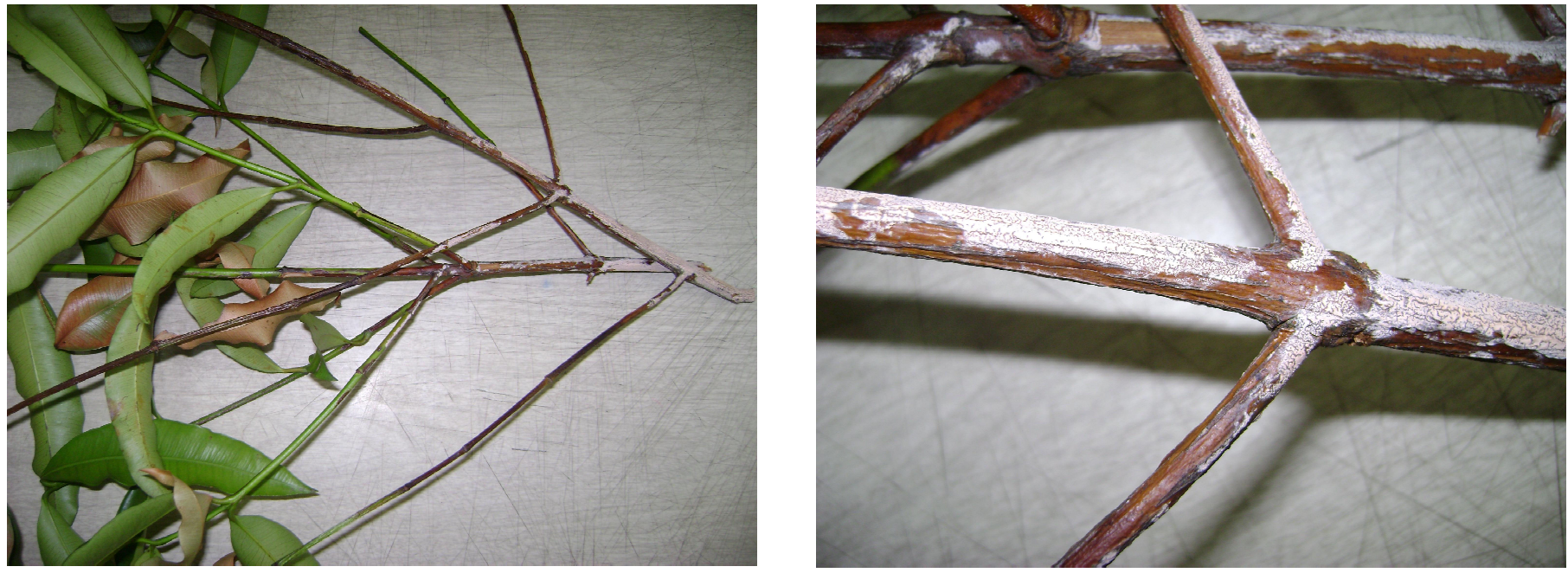

Figura 1. Ramos de bacurizinho apresentando sintomas de rubelose e sinais do fungo Erythricium salmonicolor, agente causal da doença. 